\title{
The U.F.O. and the broadening-out controversy: Crisis of farmer identity in a changing world
}

\author{
Mark Dorsey \\ This manuscript was prepared under the supervision of Professor Terry Crowley, \\ Department of History, College of Arts.
}

\begin{abstract}
This essay explores the subject of farmer identity in Ontario during the United Farmers of Ontario (UFO) administration, 1919-1923. Although a wealth of scholarly attention has been given to the UFO, the focus has conventionally only been on the politics of the group. This particular paper seeks to address a gap in the historiography of the UFO by trying to determine the extent to which farmer identity was experiencing change during the UFO's administration. Using a variety of primary source materials, this paper takes an in-depth look at how farmers saw themselves and how they were viewed by others. With a particular emphasis on how two polar-opposite personalities, E.C. Drury and J.J. Morrison, represented the conflicting opinions of the farming sector as a whole, this essay comes to the conclusion that the UFO's "broadening-out controversy" coincided with a major re-evaluation of farmer identity, the last time that such extensive discussion about the personality of agriculture took place in Canada.
\end{abstract}

$\mathrm{W}$ Then the United Farmers of Ontario (UFO) unexpectedly received the most votes in the 1919 provincial election, it seemed as though farming communities all across the province were beginning to emerge as a unified group with a distinct identity. The early twentieth century had been characterized by rural depopulation and a growing disparity between the values and interests of people on the farms and those in the towns and cities. 1919 brought hope to farmers that they could rise up as a cohesive group to a place of preeminence in society, politics and industry. However, when the UFO came to minority power, farming communities were unable to capitalize on their success by solidifying or strengthening their political control. One of the main reasons why the farmers' political movement failed was because farmers were split by the broadening-out controversy. The controversy saw UFO Secretary J.J. Morrison and Premier E.C. Drury clash over whether the group should be a class-based party or should branch out and try to promote farmers' issues in the context of a broader, more all-inclusive party identity. While it was partly a personal conflict between the politically minded Drury and the business oriented Morrison, the broadening-out controversy is significant because it represented a wider struggle within farming communities to reformulate their identity in terms of how they saw themselves and how others perceived them.

In late 1919, when the controversy surrounding the broadening-out policy was starting up, there was an immediate interest in the affair on behalf of many scholars and journalists. However, it was not only the agricultural presses who covered the debate; non-agricultural journals and the major city dallies also consistently covered the controversy and contemplated the benefits and drawbacks of Drury and Morrison's opposing positions. Interest in the broadening-out controversy and its significance continued for the rest of the century as scholars considered it from various thematic positions. Much of the historiography on the subject has focused on the conflict from a political perspective. For instance, in his seminal book on the UFO, Kerry Badgley examined how the controversy undermined the first massbased political challenge to the dominant Liberals and Tories ${ }^{1}$. Another example is David Hoffman who provided an in-depth analysis in terms of the clash between the parliamentary and mass sections of the party. ${ }^{2}$ In addition to studies of the political implications of the Drury and Morrison clash, there have also been autobiographies and biographies written on the major players in the controversy. Such documents reveal the motivations behind Drury and Morrison's respective beliefs and how those viewpoints affected the politics of Ontario. Along with political assessments and biographical sketches, there is also no shortage of overviews about the UFO controversy in the context of more comprehensive studies of a changing social order. $^{3}$

While there is no doubt that the broadening-out controversy has received its due share of scholarly attention throughout the years, there is one void in the current historiography of the subject that this paper aims to address. The clash has yet to be investigated in terms of what it reveals about changing farmer identity, especially in the 
context of increased urbanization and industrialization coupled with a perceived decrease in the importance of farmers within the provincial political and social spectrums. Understanding farmer identity is an important element within the historiography because in order to truly understand the political and social underpinnings behind the broadening-out controversy, one needs to understand a variety of issues related to how farmers were seen. There has been a significant amount of research conducted on the various factors that contribute to the creation of identity. To understand farmer identity it is imperative to use the groundwork that has already been laid out concerning theoretical approaches to identity. In particular, farmer identity during the UFO broadening-out controversy can be illuminated by being aware of nostalgic versus modern identities and group versus individual identities. ${ }^{4}$

One main factor that determines human identity is how we remember life once being. Specifically, humans often tend to look back on events with nostalgic, positive feelings about the past. The UFO ascended to provincial prominence largely because the message that they offered the populace was one that appealed to the farmers' sense of nostalgia for the way that life was once was. Prior to the beginning of the twentieth century, the majority of the population in Ontario lived on farms but by World War I that time had passed due to rural depopulation and increasing urbanization. ${ }^{5}$ Although farmers still made up a significant segment of the voting population, after the Great War it was clear that voters in large urban centers and small towns were starting to control the political affairs of the province.

Before the late nineteenth century, most farmers had little need to organize collectively in order to protect the farming industry. That being said, some farmers with a good amount of social and political initiative did participate in early political organizations for farmers such as the Patrons of Industry and the Grange. ${ }^{6}$ Despite the small but significant impact of those particular organizations, there was still no vehicle to express the collective political wishes of farmers across the province. Therefore, as industrialization and modernization took place in Ontario, farmers were unsure of where they belonged and began to think of their identity within a wider context. Aware of their decreasing importance within the political spectrum, passionate and hardworking farmers longed for the days when they were seen as dignified.

As astute politicians, both Drury and Morrison recognized the key role that nostalgia played in gaining any kind of political success. They were not alone; all of the farmer politicians who succeeded in the 1919 election played to farmers' sense of nostalgia. ${ }^{7}$ Thus, as the broadening-out controversy heated up, political rhetoric by farmers often focused on the way life used to be when farmers were lauded for their spiritual connection to the land and their contributions to the health of the province and it's people.
Besides nostalgia, psychologists have also determined that human identity is greatly affected by how we see ourselves as individuals and how we see ourselves fitting into a larger group setting. ${ }^{8}$ In the early twentieth century, various farming communities in Ontario may have all struggled with the same issues but that did not mean they could be described as a group with one solid identity. In fact, often the opposite was true. Important to remember in terms of individual versus group identity is the post-modern identity theory, which argues that we define ourselves by more than just class. ${ }^{9}$ Farmers were not just farmers; they were separate individuals whose identities were also greatly influenced by other factors as well, such as gender, race and religious allegiances.

In such a complex and varied world, farmer identity was too ambiguous to be reduced to one dominant focal point. Individuals who grew up on farms were conflicted about their place in the provincial workforce and social milieu. For instance, young farmers who were becoming adults wrestled with the idea of staying on the farm or moving to a town or city where there were more employment and social opportunities. Since most farm families had interests both on the farm and in the cities, farmers had a difficult time fitting easily into one cohesive group identity. On top of this, farmers also had trouble grouping together because each farm house was made up of distinct personalities who often disagreed on the right methods for improving the situation of farmers and promoting their collective interests. Farmers were also more isolated in terms of geography than the urban populace which prevented them from grouping together and acting as a whole.

If the social differences between farmers were not enough to fragment them as a potentially cohesive group, the tremendous range of producer groups solidified the splits. With a variety of different producer groups, came a great variety of economic and political goals. Although people outside of agricultural communities tend to assume that all farmers do the same work, the occupations of different types of farmers, such as dairy farmers and crop farmers, are quite different. For instance, the fortunes of dairy farmers depend on the market prices for products such as butter, cheese, and eggs. Crop farmers, on the other hand, are not concerned with dairy prices; they are interested in obtaining the highest possible market prices for their crops like oats, barley, rye flaxseed, potatoes, or corn.

Differences other than market concerns also existed. Crop farmers needed more space to grow their crops than was needed by dairy farmers for their operations, which is why there were large variations between the land holdings of farmers in the first part of the twentieth century. The differences between crop and dairy farmers are just two examples. Poultry fanciers and livestock farmers were also parts of the occupational sector that would have had political and economic aims that did not always align with other 
farmers. In 1926, cash receipts for livestock farmers equaled $\$ 96,882$. In contrast, poultry farmers had a total of $\$ 32,179$ in cash receipts that year. ${ }^{10}$ With such vast differences in the incomes earned by various farmers and the size of land holdings, it only makes sense that not all farmers would have shared the same outlook and identity.

Despite the vast geographical, social and economic differences amongst individual farmers which hindered them from working collectively, it would be disingenuous to suggest that there was not some sort of tangible shared identity amongst farmers. Besides the previously mentioned farmer groups such as the Patrons of Industry and the Grange, farmers had a connection to each other through publications like the Farmer's Sun newspaper. The Farmer's Sun, which featured a wide variety of farmer-related articles and advertisements, eventually played a major role in organizing support for the UFO. ${ }^{11}$ Although farmers had been unable to substantially and permanently organize prior to the UFOs emergence, the UFO's election victory proved that farmers could indeed take collective action. Farmers all shared a marginalized identity which resulted in a brief coming together for political action, an early example of the modern idea of identity politics. However, despite the fact that farmers were able to come together, the experiment was short-lived since too many farmers had contrasting identities. Since farmers were not used to thinking in terms of group identity, when they finally did create the UFO and started acting like a cohesive group, their solidarity was easily shaken by competing internal interests.

Another way of viewing the makeup of the farmer identity during the UFO's prime is to consider how individual farmers dealt differently with the pressures and tensions caused by the fast pace of modernizing change. Psychologists have determined that humans can be broken down into those who have progressive personalities and those who have stable personalities. ${ }^{12}$ Both possibilities represent the main ways in which people look at the world and their place in it. At its core, the contrast of identities between Drury and Morrison can be seen as a conflict between those who favoured progressive identities and those who favoured a more unwavering, conventional identity. Drury was a man with one foot on the farm and one foot in the city. A natural politician, Drury epitomized the fragmented identities of many farmers who had been raised as farmers but grew to find that they had much in common with the city folk they encountered. Drury's views on the shared interests of the different social classes were perhaps most evident in his post-nomination speech regarding the UFO:

But in a very real sense we represent not alone the forty percent of the people who are on the farms, but also the great bulk of the common people of all classes, the people who are desirous of good government, of stability, efficiency and economy, and of the fair and equal enforcement of law. ${ }^{13}$
Morrison was admittedly less interested in finding common political ground with people in the cities, at least politically. If Drury represented the modern and fragmented farmer, Morrison was the quintessential farmer's farmer who was isolationist and distrustful of the urban populace. Drury fashioned himself as a progressive politician who could look beyond occupation and geographical location, which is why he adopted the broadening-out policy. Morrison, on the other hand, was much more conservative and wanted to focus exclusively on the farmers' class. With the two main figures of the UFO representing almost polar opposite approaches to identity, it is clear that other farmers were struggling to either reformulate them in new and varied ways or stay the same.

Along with a look at the role of nostalgia and individual versus group identity, any theoretical meditation on farmer identity during the time of the UFO needs to address the fact that farmers were only one segment of a society going through major changes.

While industrialization and modernization have been previously brought up as factors that created a rapid pace of change, it is also important to remember that the UFO emerged in the wake of World War I. The 1919 Paris Peace Conference not only marked the end of that conflict but also signaled the beginning of Canada's emergence as a fully independent nation. Marketplaces were increasingly interconnected and Ontario farmers faced growing competition from other countries due to rapid advances in transportation technologies. The early twentieth century brought with it a higher cost of living which caused uncertainty at all levels of society. For instance, the Winnipeg General Strike proved that the labouring classes were also struggling with their group identity. ${ }^{14}$ In fact, the changes faced by the labouring and farming classes were similar in that both segments of society wanted a major reconstruction of the economic system. Even though they were largely peripheral entities, the UFO and Labour parties managed to form an alliance of mutual hostility that was able to briefly compete with the dominant Tories and Liberals in the provincial parliament. ${ }^{15}$ There was no doubt that farmers were facing huge changes during the time of the UFO but farmers were one of many groups facing changes. Determining how farmers would work with other troubled segments of society would ultimately decide the complicated makeup of farmer identity.

Using theoretical methods from the field of psychology can provide modern day historians with insights, but in order to truly understand farmer identity, it is imperative to know how farmers saw themselves. A main reason behind the UFO's electoral success was the fact that farmers were completely dissatisfied with the manner in which they had been treated by previous governments. There were a number of specific policies pursued by the traditional political parties which irritated farmer communities. The war was also significant for farmers because when the government tried to 
enact conscription in 1917, farmers protested en masse, making it the most passionate political issue for farmers since the tariff protests at the turn of the century. ${ }^{16}$ So many farmers had already considered the economic policies pursued by the Liberal and Conservative parties as predatory towards farmers, when conscription left them with a severe labour disadvantage, farmers started agitating for political change. ${ }^{17}$ After the war, farmers expected to have an increased voice in politics; however, there seemed to be no pressing need for the traditional parties to incorporate more farmer ideas into their platforms, especially since an unorganized farmers class was not perceived as much of a political threat. When farmers realized that their voices were not being heard, they considered it an offensive lack of appreciation for the increased wartime production and other important roles that farmers played in war effort. ${ }^{18}$ Although there had been a significant build up of farmer grievances leading to the creation of the UFO, complaints by farmers were nothing new. In fact, a large part of farmer identity was centered on the idea that farmers were constantly facing hardships from both the natural and social worlds. However, with the emergence of the UFO there was concerted effort on behalf of Ontario farmers to shake off the stigma of longsuffering, self-sufficient citizens who only acted as individuals and left politics to others. ${ }^{19}$

The UFO's commitment to shedding the stigma of suffering and having farmers take control of their own destiny was constantly reiterated by Drury. Even long before he became a politician, Drury used the rhetoric of change by arguing that "farmers should be the leaders of our nation in all that is best, and until that is attained they should not rest content with themselves". ${ }^{20}$ Drury was not the only one trying to stimulate a change in the social position of the farmer; the effort to create a new and improved farmer identity was even evident in the UFO's motto: "Raising the rural people to a higher plane of civilization." 21 The mantra, repeated again and again in UFO publications, acknowledged that farmers were not conventionally considered high class citizens but had the ability to be so, if only they supported the UFO.

As much as farmers sought to be the sole formulators of their own identity it is human nature to determine one's own identity in relation to other segments of society. Farmers, in particular, constructed their self-identity in relation to other classes since it seemed as though there were vast differences between themselves and the urban populaces. It has already been discussed that farmers thought urban political parties had ruined the market and only served their own interests. Farmers also began to fear urban control in all aspects of politics and increasingly saw their own identity in direct confrontation with urban populace, who might as well have been foreign to many isolated farm families. ${ }^{22}$ If competing market interests were not enough of a partition between farm and city folks, there was also a perceived moral divide between the city and the farm. While city folk may have seen farmland as gray, dusty and drab, farmers saw their lands as pastoral paradises, especially compared to cramped urban centers which were growing at astounding rates. The pace of farm life was slow and farming communities were predominately conservative. Farmers saw the city as an unhealthy influence on the moral character of the people. Farmers often relished their isolation because it seemed as though life away from the distractions of the city placed the focus on family and community. ${ }^{23}$ Prior to the early twentieth century, the differences between the farms and the cities were noticeable; however, the differences had never really actualized themselves in terms of real group separation. By the time the UFO developed, the differences were much clearer, largely because groups such as the UFO were constantly reiterating the contrast.

Despite the fact that the UFO and other organizations tried to make obvious the differences between the farm and the city, the differences between the two competing segments of society may not have seemed that simple for individual farmers. For instance, farming communities were often filled with individuals who were not entirely sure where to commit their economic alliances. The rapid pace of industrial change brought about the rise of labour unions to protect certain industries in the late nineteenth century. Thus, a major challenge facing farmers was whether they considered themselves labouring people, business people, or a distinctive combination of both. In fact, Drury's entire position throughout the broadening-out controversy could be said to be driven by the commonalities he found between the labour and farm movements. As a businessman, it would seem that Morrison would have had contemplated an alliance with businessmen in the city; nevertheless, Morrison clearly saw the two types of business interests as vastly different in the context of group government which is why he vehemently opposed the UFO alliances with urban workers and the labour movement.

Putting farmer identity in the context of its time and searching for how farmers constructed their self-identity are important factors in determining farmer identity in the time of the UFO; however, it is also imperative to seek out the ways that other elements in society saw farmers. At the same time that farmers were trying to shake off the old stigma of suffering, the other segments of society proved that old stereotypes die hard. In the eyes of most of their non-farming contemporaries, farmers may have suffered but were responsible for all of the sufferings brought on them. Many city folks felt that farmers were living a filthy, unkempt and backwards life that left them ignorant of affairs beyond their own homesteads and local markets. ${ }^{24}$ Most farmers were aware of the insults being hurled at them by city folks and sought to defend themselves. WLS, a farmer from Clarke Township writing to a newspaper in 1919, had particularly harsh words for detractors of the farmers: 
When will some of these city blatherskites give farmers credit for the possession of a little ordinary horse sense? When will they learn that when the average city man talks good roads farmers know that the one thing the talker has in mind is a beautiful rural highway over which he can have his little joy ride - at the expense of the farmers who have to pay for the road? ${ }^{25}$

As WLS argued, city people who espoused the backwardness of farmers were just as ignorant as they were accusing farmers of being since there were many dynamic farmers who were engaged and important contributors to their communities, the province and the nation. One reason for the UFOs success was that people in the city hardly ever considered what farmers were doing, let alone the fact that they were starting to build a political machine that would eventually compete with the dominant parties.

The fact that farmers were perceived as dumb meant that many urbanites did not see them as a political threat until it was much too late to react with their own coalition of interests. Arthur Meighen, whose first term as Prime Minister lasted from 1920-21, admitted that he failed to see the farmers' position and, as a result, suffered the political consequences. ${ }^{26}$ The UFO's election victory may have forced others in the province to recognize the renewed social and political prominence of farmers but that did not mean that non-farmers suddenly cared about farming issues. Urbanites and other segments of society cared more about getting the farmers out of power and back into a subordinate place where it was felt they belonged. Drury's broadening-out policy had no appeal because urban-based businesses were not interested in joining a "broadened out" farmer's party. G Howard Ferguson, the Conservative Premier who succeeded Drury, was downright hostile to the farmer-labour movement and the subsidies given to the farming industry. Ferguson even went as far as accusing Drury of degrading labour conditions so that city men would return to the farms. ${ }^{27}$ Both Meighen and Ferguson viewed farmers as a negative influence on the provincial economy and their sentiments represented the feelings of most urban and town voters who were extremely distrustful of the farmers' political motivations.

Besides the words of urban-based politicians who were the contemporaries of the UFO, most of the evidence we have of urban hostility towards the farming class comes from newspaper accounts. In a time before around-the-clock television news stations and internet news sites, the power of the press was at its strongest since newspapers controlled the flow of information. The biggest downfall to Drury's broadening-out policy was that he never managed to convince the urban presses that a farmer-urban coalition could actually benefit the cities. ${ }^{28}$ Even before the UFO's tenuous reign, there was often outright hostility towards farmers in the cities. For example, in an article entitled "The
Farmer's Remonstrance", written about the farmer's conscription protest in 1918, the protesting farmers were called a "filthy lot, unshaven and unkempt, who had better remained at home attending to their work" ${ }^{29}$ Proof that the farmers' party had limited support from the urban daily papers was not just evident in what the papers said; it was also plainly obvious in what they did not say, specifically referring to the fact that most of them did not even print the UFO's political programme. ${ }^{30}$ Many city papers misunderstood or misrepresented the form of socialism that farmers were proposing. As a result, farmers were often wrongfully painted farmers as Reds or Bolsheviks, the ultimate form of fear-mongering at a time when the communist scare had gripped Canada and the US. ${ }^{31}$ In case the urban electorate was not scared of the "Red farmers", urban editorials would sometimes take the opposite approach and label farmers as free traders who were trying to avoid taxes. $^{32}$

One exception to the rule of overwhelming opposition to farmers in the press was The Globe, a Toronto-based paper. This "city paper" was against the UFO government but backed Drury in his bid to broaden-out the party. Thus, articles from The Globe are pro-Drury yet still somewhat antagonistic towards the farmers' class as a whole. Although Drury may have believed that the paper shared his vision, Morrison was cynical about their support. He felt as though The Globe, which traditionally supported the Liberal Party, was supporting Drury's scheme in order to "steal" the UFO for the Liberals. ${ }^{33}$ In the end, minimal support for Drury from one city paper was not enough to save his plan of broadening-out. The inability of the UFO to express itself to the urban electorate through the press turned out to be one of the major weaknesses that befell the organization.

The way that farmers saw themselves, were seen by others, and are seen by modern historians, are all important factors in determining farmer identity; nevertheless, since farmer identity is being considered in the context of the UFO and the broadening-out controversy, it is imperative to consider in-depth the main personalities in the conflict: Drury and Morrison. In fact, it could be said that at its core the broadening-out controversy is a tale of two personalities representing two very different types of farmer identities. During the clash there were a lot of suggestions that the entire controversy was less about politics and more about two stubborn individuals with vastly different identities. However, despite the difference in personalities between the two, there was a time when the hostility between them was not as well known. In fact, they even had a pleasant working relationship at one point, especially during the fall of 1913 when the two men were on the same Grange committee created to centralize local farm organizations. ${ }^{34}$

When the UFO first received the highest number of seats in the 1919 election, there was no established party leader to serve as figurehead for the group. During a rushed meeting to decide who would become Ontario's new Premier, Morrison 
was offered the job but declined in order to remain as UFO secretary. Ironically, it was Morrison who then nominated Drury for Premier since they had a long, personal relationship prior to the election victory and Morrison did not see a more suitable leader than Drury. However, in spite of Morrison's support for Drury's nomination, they had in fact clashed over issues prior to the broadening-out split, most notably their differing stances on conscription. Late in his life, Morrison would admit that it had always rubbed him the wrong way that Drury refused to have anything to do with the conscription effort or presentation. ${ }^{35}$

When Morrison voiced immediate opposition to the plan of broadening-out the UFO electorate, countless editorials asserted that the conflict was personal since Drury and Morrison had already been at odds with each other over a variety of issues. ${ }^{36}$ Both men quickly became aware that there were rumblings in farm communities that the clash was not about politics, but was about a personality difference. As a result, Drury and Morrison went out of their way in speeches and press releases to present the entire issue as an ideological clash and not a personal conflict. Drury, who consistently tried to appear rational and not driven by emotion, called Morrison "gentlemanly" throughout their quarrel ${ }^{37}$ However, despite Drury's attempts to elevate the broadening-out controversy beyond pettiness, there were many people who were convinced it was a personal feud and thought the two men would destroy the entire agrarian movement while trying to defeat each other's position.

Some farmers vilified Morrison for opposing Drury, calling him childish and hostile, like a "woman scorned". In particular, many Drury supporters were irked that Morrison refused to serve as Premier, only to find fault in someone who took the job and tried their best. ${ }^{38}$ Thomas Alexander Crerar, who was Minister of Agriculture under Borden's Conservative government, was particularly critical of Morrison's ability to work with others. Crerar felt that Morrison had a "hard shell partisan mind" and that his actions jeopardized the chances of attracting others to the UFO party. ${ }^{39}$ On the other hand, others defended Morrison by claiming he was doing his duty as head of the UFO business interests to make sure that politicians like Drury did not highjack the goals of the entire organization for their own political gains. ${ }^{40}$

Drury, for his part, was also not immune to criticism about his motivations behind pursuing the broadening-out policy. A common criticism against Drury was that he was out of touch with the farming communities he was representing. He was often depicted as being part of the intelligentsia, a group of college farmers who were regarded as having impractical ideas of a Utopia where farmers and big business could coexist in harmony. ${ }^{41}$ Editorials in the Toronto Daily Star suggested that Drury's detachment from his roots was an unavoidable consequence of being an elected politician, since all elected members eventually lose touch with the identities of those who elected them. ${ }^{42}$ Morrison, in particular, continually questioned the legitimacy of Drury's farmer identity. For example, he attacked Drury's government for the Last Awful Night controversy in which UFO MPPs were caught drinking during prohibition. The controversy was particularly damning since conservative farm communities often led the lobbying for prohibition as they had been suffereing deeply from the effects of alcohol. ${ }^{43}$ Drury did not take the charges against his farmer credibility lightly. In order to prove his legitimacy as a voice for Ontario's farmers, he responded by moving back to the farm and fashioning himself as a "son of the soil". ${ }^{44}$ Drury even tried to turn the accusations of detachment around on Morrison by suggesting that he was closer to farms then the head of farm organizations, a pointed jab at Morrison. ${ }^{45}$ For many farmers though, Drury did not need to prove himself and they defended him for being realistic and proving that farmers were not selfish with their newfound political control.

While some saw the broadening-out controversy as a mainly personal conflict, others viewed it as more a case of an inherent difference between a politician-farmer and a businessman-farmer. Initially, the UFO was never meant to be a political machine. Proof of this is the fact that the first UFO by-laws and constitution made no mention of politics. The group only ever seriously entered politics because they were forced to after their election victories. ${ }^{46}$ Before they were thrust into the political spotlight, Morrison, an early leader of the group, was inherently anti-political. Still holding onto the romantic "yeomanry" view of the farmer, he had lost faith in any political party to truly fight for the issues important to farmers. ${ }^{47}$ In direct contrast to Morrison's political hesitations, Drury was a politician at heart. Wellspoken and politically oriented, Drury sought the spotlight that Morrison shunned. However, Drury's political eagerness rubbed some the wrong way and many people thought that once he was elected, Drury abandoned the farmers' cause.

When Drury asserted that the support of the urban vote was essential to the achievement of the UFOs objectives, he assumed that the majority of farmers were on board with broadening-out, which is why he vigorously pursued the policy. In actuality, most farmers cared more about economic policies than making friends with the urban populace. Drury's main goal as political leader of the UFO was to widen his support base and act as an effective coalition Premier, whereas Morrison's was to strengthen the multimillion dollar business. Therefore, the Drury-Morrison split can be viewed as a conflict between the parliamentary and mass sections of the party. ${ }^{48}$ Some farmers, especially the politician-farmers, had one foot in the city and one on the farm, while strictly businessmen-farmers cared about business and did not care about pandering to the city. It was no surprise then that both types of workers had a much different self-identity. The difference between farmer- 
politicians and farmer-businessmen proved to be fatal for the UFO since the group could never reconcile the divergences between the two opposing viewpoints within the farmers' class.

Drury and Morrison may have had their differences both personally and politically, but their encounters with each other ensured that their identities would not remain static throughout the UFO's reign. This is because a key element of the human psyche is our internal-external dialectic, which causes us to modify our identity due to external pressure. ${ }^{49}$ Soon after getting chosen as Premier, Drury wanted to move beyond occupational sector and for this reason he pursued the broadening-out policy. However, the policy of inclusion did not always hold such an elevated place in Drury's public persona. Since he never articulated the idea before becoming Premier it is assumed that he came up with the idea after being influenced by his time in parliament. Morrison, who never had to deal with the pressures of parliament but had to answer to business members of the UFO, showed immediate disapproval to broadening out. Although Morrison's official position on the policy never changed, as a result of the conflict, he was forced to come out of his shell and start making consistent public statements and appearances. Similarly, ordinary farmers were forced to think about their identities in new ways as the marketplace became more complex. Farmers were required to be businessmen as well as agriculturalists. It could be argued that Morrison represented a conservative and static farmer identity that was concerned with internal issues whereas Drury embodied a fluid, progressive identity that viewed farmers as one element within a larger societal context. Drury even went so far as to eventually drop the "farmers" label and create the People's Progressive Party (PPP) after the UFO had disbanded. However, the PPP only had limited success since the electoral community of farmers had already been divided. $^{50}$

Despite early hopes that the political success of the UFO would usher farmers in a period that would see other farmers emerge with a new identity as leaders and trendsetters of society, lasting social influence never came. As a study of the broadening-out controversy reveals, one of the reasons farmers were not able to maintain a unified front was because there was no common identity among them. Farmers, who had previously stayed largely out of politics, were not used to thinking of themselves in terms of group identity. Therefore, when the UFO was thrust into the political spotlight, farmers had not taken the time yet as a group to decide how they wanted to present themselves to the outside world. Some farmers, like Drury, saw their farmer identity as only a part, albeit a large part, of a complex identity that had much in common with the populations living in the towns and cities. Others, like Morrison, did not find much in common with town and city folk and sought to promote that difference as part of their identity. The inherent conflict between the two different identities represented by Drury and Morrison manifested itself in the broadening-out controversy, the last time that such extensive discussion about the personality of agriculture took place in Canada.

\section{ENDNOTES}

${ }^{1}$ Kerry Badgley, Ringing in the Common Love of Good: The United Farmers of Ontario, 1914-1926 (Montreal: McGillQueen's University Press, 2000).

${ }^{2}$ David Hoffman, "Intra-Party Democracy: A Case Study,"

The Canadian Journal of Economics and Political Science

27, no. 2 (1961): 223-235.

${ }^{3}$ See James Naylor, The New Democracy: Challenging the Social Order in Industrial Ontario, 1914-1925. Buffalo:

University of Toronto Press, 1991.

${ }^{4}$ Theodore Sarbin and Karl Scheibe. Studies in Social

Identity (New York: Praeger, 1983), 14.

${ }^{5}$ Royce MacGillivray. The Slopes of the Andes: Four Essays on the Rural Myth in Ontario (Belleville: Mika Publishing Company, 1990) 22.

${ }^{6}$ Terry Crowley, "JJ Morrison and the Transition in

Canadian Farm Movements during the Early Twentieth

Century," Agricultural History 71, no. 3 (1997):

${ }^{7}$ Russell G Hann, Farmer's Confront Industrialism: Some

Historical Perspectives on Ontario Agrarian Movements

(Toronto: New Hogtown Press, 1975), 10-13.

${ }^{8}$ Sarbin and Scheibe, 281.

${ }^{9}$ Sarbin and Scheibe, 9.

${ }^{10}$ F. H. Leacy, Historical Statistics of Canada, Catalogue (Statistics Canada); 11-15. $2^{\text {nd }}$ ed. F.H. Leacy, editor.

[Ottawa]:Statistics Canada, 1983.

${ }^{11}$ Badgley, 51.

${ }^{12}$ Sarbin and Scheibe, 27.

${ }^{13}$ Ernest Charles Drury, "Choice of E C Drury as Leader to be Ratified by the UFO," The Farmer's Sun, Nov 5, 1919.

${ }^{14}$ Naylor, 50.

15 "The UFO Political Programme," The Canadian Forum xiii, no. 149 (1933): 123.

${ }^{16}$ Charles M Johnston, EC Drury: Agrarian Idealist

(Toronto: University of Toronto Press, 1986), 43.

${ }^{17}$ James Edgar Rea, TA Crerar: A Political Life (Kingston:

McGill-Queen's Press, 1997), 20.

${ }^{18}$ Rea, 22.

${ }^{19}$ C B Sissons, "The Farmers' Case," The Canadian Forum 11, (1931): 129.

${ }^{20}$ Ernest Charles Drury, "The Social Position of the Farmer," OAC Review 15, (May 1903): 193.

${ }^{21}$ Hillman, 38.

${ }^{22}$ M H Staples, "The Genesis of the United Farmers," The Canadian Forum 1, (Jan 1921): 262-263.

${ }^{23}$ Royce MacGillvray, The Slopes of the Andes: Four Essays on the Rural Myth in Ontario (Belleville: Mika Publishing Company, 1990), 20. 
${ }^{24}$ J Francis White, "The Farmer's Problem," The Canadian Forum 5, (Dec 1924): 108.

${ }^{25}$ W L S, "News and Views from the Farm," The Weekly Sun, Jan 15, 1919.

${ }^{26}$ Ernest Charles Drury, Farmer Premier: Memoirs of the Honourable E C Drury (Toronto: McClelland and Stewart, 1966), 77.

${ }^{27}$ Peter Oliver, G Howard Ferguson: Ontario Tory (Toronto: University of Toronto Press, 1977), 130.

${ }^{28}$ Oliver, 103.

29 “The Farmers' Remonstrance," Toronto Daily Star, May 14, 1918.

30 "The UFO Political Programme", 123.

${ }^{31}$ E A Beder, "Agriculture and Socialism," The Canadian Forum 13, (Jan 1933): 332.

${ }^{32}$ Sissons, 394.

${ }^{33}$ William Bruce Hillman, JJ Morrison: A Farmer Politician in an Era of Social Change (London: University of Western Ontario Press, 1974): 55.

${ }^{34}$ JJ Morrison, "Memoirs of JJ Morrison", $R$ Alex Sim Collective, 14

${ }^{35}$ Morrison, 31.

36 "The Cause of the Clash," The Globe, Apr 18, 1923.

${ }^{37}$ Ernest Charles Drury, Farmer Premier: Memoirs of the Honourable EC Drury (Toronto: McClelland and Stewart, 1966), 55.

38 "The Cause of the Clash".

${ }^{39}$ Edgar James Rea, T.A. Crerar: A Political Life (Kingston: McGill-Queen's Press, 1997), 33.

40 “JJ Morrison and the Drury Government," Toronto Daily Star, Aug 27, 1920.

41 "Veteran Secretary Declared Moving Spirit behind United Farmer Movement in Ontario," Farmer's Sun, Aug 6, 1931.

42 "Premier Drury and Secretary Morrison", Toronto Daily Star, Aug 28, 1920.

${ }^{43}$ Hillman. 37.

44 Johnston, 40.

45 “Drury's Washago Speech," Toronto Daily Star, Aug 7, 1923.

46 Staples, 263.

${ }^{47}$ Hillman, iv.

${ }^{48}$ Hoffman, 237.

${ }^{49}$ Sarbin and Scheibe, 165.

50 Johnston, 190.

\section{REFERENCES}

Badgley, Kerry. Ringing in the Love of Common Good: The United Farmers of Ontario, 1914-1926. Montreal: McGill-Queen's University Press, 2000.

Canadian Forum 1 (1921); 11 (1931); 14(1933).

Leacy, F. H. Historical Statistics of Canada. Catalogue (Statistics Canada); 11-51. 2nd ed. F.H. Leacy, editor. [Ottawa]: Statistics Canada, 1983.

Crowley, Terry. "JJ Morrison and the Transition in Canadian Farm Movements during the Early Twentieth Century". Agricultural History. Vol. 71, No. 3 (Summer 1997): 330-357.

Drury, Ernest Charles. Farmer Premier: Memoirs of the Honourable E.C. Drury. Toronto: McClelland and Stewart, 1966.

Hann, Russell G. Farmer's Confront Industrialism: Some Historical Perspectives on Ontario Agrarian Movements. Toronto: New Hogtown Press, 1975.

Hillman, William Bruce. J.J. Morrison: A Farmer Politician in an Era of Social Change. London: University of Western Ontario Press, 1974.

Hoffman, David. "Intra-Party Democracy: A Case Study". The Canadian Journal of Economics and Political Science. Vol. 27, No. 2 (May, 1961): 223-235.

Johnston, Charles M. E.C. Drury: Agrarian Idealist. Toronto: University of Toronto Press, 1986.

Leonard Harman / United Co-Operatives of Ontario Collection, \& Drury, E. (1919). Clippings, photos and correspondence concerning Ernest Charles Drury, Premier of Ontario from 1919-1923, 1919-1973. Unpublished manuscript.

MacGillivray, Royce. The Slopes of the Andes: Four Essays on the Rural Myth in Ontario. Belleville: Mika Publishing Company, 1990.

Naylor, James. The New Democracy: Challenging the Social Order in Industrial Ontario, 1914-1925. Buffalo: University of Toronto Press, 1991.

Oliver, Peter. G Howard Ferguson: Ontario Tory. Toronto: University of Toronto Press, 1977.

Ontario Agricultural College Student Newspapers. (1889).

O.A.C. Review, V.1 (1889-90) - V.73 (1961). Unpublished manuscript.

R. Alex Sim Collection, Sim, R. A., Morrison, J. J. (. )., \& Morrison, C. A. (1952). Memoirs of J.J. Morrison. Unpublished manuscript.

Rea, James Edgar. T.A. Crerar: A Political Life. Kingston: McGill-Queen's Press, 1997.

Scheibe, Karl and Theodore Sarbin. Studies in Social Identity. New York: Praeger, 1983.

Unknown. (1919, Jan. 15). Unknown. Farmer's Sun. 